\title{
Efficiency Improvement in the Assembly Line with the Application of Assembly Line Balancing Method
}

\author{
Akshay C Shettigar, Hamritha S, A Balakrishna
}

\begin{abstract}
The focus of this paper is on the improvement of the assembly line by means of assembly line balancing approaches. The assembly line balancing is about evenly distribution of the work load among the workstations without violating the precedence and cycle time specifications. The twoassembly line balancing tactics specifically Largest candidate rule method (LCR) and Kilbridge and Westercolumn method (KWC) are utilized to strengthen the efficiency of assembly line by minimizing the number of workstations and thereby reducing the balance delay of the assembly line.Line balancing is an effective method to enhance the throughput of assembly line by reducing non-value-added activities. The technique followed includes calculation of cycle time of the process, identifying the non-value-added activities, calculating overall work load on station and distribution of work load on each station by the method of line balancing.

This paper broadens the productivity and effectivity of an Excavator Assembly line in ABC organization. Line balancing is used to measure the efficiency of the line and later used to measure the effectiveness of the proposed solution. Multiple approaches have been proposed based on the time study carried out. Evaluation of the outcomes of the proposed assembly line suggests that the line efficiency of the excavator's assembly line is improved from $71.27 \%$ to $77.44 \%$
\end{abstract}

Index Terms - About Assembly line balancing, Cycle time study, Non-Value added activities, Work load

\section{INTRODUCTION}

Excavator is one of the heavy construction equipment that called as diggers, formally known as JCB. They vary in sizes and the capacity of the work. In the assembly of the excavator, many OEM components are used. In the detailed study of the assembly line it was observed that they have feeder stations and main stations. Over all they had 9 main stations and 15 feeder stations. It was observed that each station had different cycle time. Some feeder stations were depending on the other stations in order to process the work. This clearly said that the assembly line was not balanced and it led to un-necessary bottle necks. Due to which the lead time of the process was very high. Line balancing plays an important role in any manufacturing nit because assembly line is on the crucial area in the manufacturing sector whose lead time if not maintained, customer demand will not be achieved on time. Hence forth in order to satisfy

Revised Manuscript Received on July 10, 2019

Akshay C Shettigar, Student, Ramaiah Institute of Technology, Bengaluru, Karnataka, India. (E-mail: akshaycshettigar95@gmail.com)

Hamritha S, Assistant Professor, Industrial Engineering and Management,Ramaiah Institute of Technology. Bengaluru, Karnataka, India. (E-mail: hamritha.shankar@gmail.com)

A Balakrishna, Associate Professor, Industrial Engineering and Management,Ramaiah Institute of Technology. Bengaluru, Karnataka, India. (E-mail: balki004@gmail.com) has parts like dipper, cab on rotating platform. It is also

the customer by meeting their demand on time, better lead time must be maintain in the assembly line. This clearly states that the any activity performed in the assembly line must add value to the customer.

A detailed study was carried out in the excavator assembly line to identify the bottle necks, idle time, delay and others draw backs which caused higher lead time. Cycle time study was conducted initially to obtain the cycle time study of each station. Along with this a detailed study was also carried out in order to observe the activities that were performed in each process. By analyzing these study, non value activities were identified which cause one or the other type of wastes in the assembly line. In order to eliminate the waste and to balance the assembly line, one of the line balancing techniques - Largest Candidate Rule was carried out. Initial layout was drawn and the calculations were done for the line efficiency and it was observed to be $71 \%$. Some of the wastes like Fixing the eye bolts, disassembling hoses, lifting placing and movement of MCV instations or feeders which were observed were eliminated. These led to reduction in number of stations.

At each workstation, work is performed on a product both by way of including elements or through completing assembly operations. The work finished at every station is made from many bits of labor, termed tasks, elements, and work units. Such responsibilities are described by means of motion-time analysis. The objectives of line balancing include the maximization of production rate and minimization of number of workstations. Line balancing is about the grouping the workstations in an efficient manner in order to get optimal or most efficient feasible solution for the assembly line balancing problem

\section{LITERATURE SURVEY}

Nurul NazeerahMishan and Masine Md Tap "Increasing Line Efficiency By Using Timestudy And Line Balancing In A Food Manufacturing Company" studied the bun manufacturing process and identified the line efficiency and balance loss was $30 \%$ and $69 \%$ respectively. They used the line balancing method and work study to study the process and identified that the dough maker process was the non value added activity and needs improvement in the activity. They suggested a new machine and improvement in the process and the line balance losses was reduced to $23 \%$ and efficiency was increased to $76 \%$. [1]

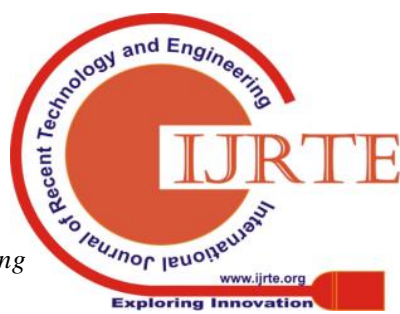




\section{EFFICIENCY IMPROVEMENT IN THE ASSEMBLY LINE WITH THE APPLICATION OF ASSEMBLY LINE BALANCING METHOD}

Anil Jaggi et al, “ Application of Line-balancing to Minimize the Idle Time of Workstations in the Production Line with Special Reference to Automobile Industry" This paper concentrates on the improving the process by targeting the idle time and on value added activities in the production line of an automobile industry. Upon detailed studied and use of the modern lean tools they improved the efficiency to $77 \%$ by reducing the idle time across all the stations. By placing the lines in an orderly manner based on the requirement and process improvement it was also observed that the storage area was needed in between few stations so that the process can move smoothly. [2]

SwapnilT. Firake "productivity improvement of automotive assembly line through line balancing" The author studied the line balance in the automotive industry where poor layout design was observed, which led to the bottle neck between the work stations and increase in lead time. The time consuming activities were reduced with the help of detailed observations and process improvement. Balancing of the production was done with the help of cycle time study, down time and in turn reduces the lead time showing increase in the efficiency of the assembly line. [3]

Dr. Ikon et al, "Line Balancing and Performance: A Study of SelectedBreweriesin Anambra State, Nigeria" Author presents a heuristic procedure for improving the performance of the assembly line of beverage manufacturing company. He used ranked Positional weight method inorder to balance the production process and was found that the labor cost was reduced by $1.3 \%$ and line efficiency was increased to $18.9 \%$. Author also suggested that the inspection should be performed with new technologies and not with the traditional approach. [4]

K Syahputri, R M Sari, Anizar, I Rizkya, J Leviza and I Siregar, "Improving Assembly Line Balancing Using MoodieYoungMethods on Dump Truck Production". Authors in this work studied seven work stations in the production line where bottle necks were due to very high difference in the cycle time. It was observed that the bottlenecks in the work station led to delay in the delivery of the product and increased the completion time. Moodie young method help the authors to reduce the balance delay to $19.18 \%$ from 53.86 and increased the smoothness in the assembly line by increasing the efficiency to $75 \%$. [5]

From the detailed literature survey, it is evident that the line balance and the balance losses can be improved and reduced respectively with the help of elimination of bottle necks, processes simplification and eliminating the non value added activities in the area of interests. In order to achieve this work study and cycle time study plays a very vital role to understand the process and cycle time. By conducting these tools and techniques a sure improvement can be observed in the research.

III. METHODOLOGY

\begin{tabular}{|l|l|l|l|l|}
\hline SL.NO & $\begin{array}{l}\text { STATION } \\
\text { S \& } \\
\text { FEEDER } \\
\text { S }\end{array}$ & $\begin{array}{l}\text { NOTA } \\
\text { TIONS }\end{array}$ & $\begin{array}{l}\text { CYCLE } \\
\text { TIME } \\
\text { (MIN) }\end{array}$ & $\begin{array}{l}\text { PRECEDEN } \\
\text { CE }\end{array}$ \\
\hline 1 & $\begin{array}{l}\text { FEEDER } \\
8\end{array}$ & F-8 & 67 & -- \\
\hline
\end{tabular}

\begin{tabular}{|c|c|c|c|c|}
\hline 2 & \begin{tabular}{|l} 
FEEDER \\
1
\end{tabular} & F-1 & $42: 50$ & F-8 \\
\hline 3 & $\begin{array}{l}\text { STATION } \\
1\end{array}$ & S-1 & 79:50 & F-1, F-8 \\
\hline 4 & $\begin{array}{l}\text { FEEDER } \\
2\end{array}$ & F-2 & 80 & S-1 \\
\hline 5 & $\begin{array}{l}\text { STATION } \\
2\end{array}$ & S-2 & 120 & F-2, S-1, F-9 \\
\hline 6 & $\begin{array}{l}\text { FEEDER } \\
3\end{array}$ & F-3 & 42 & S-2 \\
\hline 7 & $\begin{array}{l}\text { STATION } \\
3\end{array}$ & S-3 & 61 & F-3, S-2 \\
\hline 8 & $\begin{array}{l}\text { FEEDER } \\
4\end{array}$ & F-4 & 69 & S-3 \\
\hline 9 & $\begin{array}{l}\text { STATION } \\
4\end{array}$ & S-4 & 111 & S-3, F-4 \\
\hline 10 & $\begin{array}{l}\text { STATION } \\
5\end{array}$ & S-5 & 74 & S-4, F-13 \\
\hline 11 & $\begin{array}{l}\text { FEEDER } \\
5\end{array}$ & F-5 & 8 & S-5 \\
\hline 12 & $\begin{array}{l}\text { STATION } \\
6\end{array}$ & S-6 & 62 & S-5, F-5 \\
\hline 13 & $\begin{array}{l}\text { STATION } \\
7\end{array}$ & S-7 & 27 & S-6 \\
\hline 14 & $\begin{array}{l}\text { FEEDER } \\
6\end{array}$ & F-6 & 16 & S-7 \\
\hline 15 & $\begin{array}{l}\text { STATION } \\
8 \\
\end{array}$ & S-8 & $43: 30$ & S-7, F-6 \\
\hline 16 & $\begin{array}{l}\text { FEEDER } \\
15,\end{array}$ & F-15, & 59 & S-8 \\
\hline 17 & $\begin{array}{l}\text { FEEDER } \\
7 \\
\end{array}$ & F-7 & 28 & F-15' \\
\hline 18 & $\begin{array}{l}\text { STATION } \\
9\end{array}$ & S-9 & 82 & S-8, F-7 \\
\hline 19 & $\begin{array}{l}\text { FEEDER } \\
15,\end{array}$ & F-15" & 50 & S-9 \\
\hline 20 & $\begin{array}{l}\text { FEEDER } \\
9\end{array}$ & F-9 & 152 & S-1 \\
\hline 21 & \begin{tabular}{|l|} 
FEEDER \\
10 \\
\end{tabular} & F-10 & $55: 40$ & S-4 \\
\hline 22 & \begin{tabular}{|l|} 
FEEDER \\
11 \\
\end{tabular} & F-11 & $66: 30$ & F-10 \\
\hline 23 & \begin{tabular}{|l|} 
FEEDER \\
12 \\
\end{tabular} & F-12 & $38: 20$ & F-11 \\
\hline 24 & \begin{tabular}{|l|} 
FEEDER \\
13
\end{tabular} & F-13 & 82 & F-12 \\
\hline
\end{tabular}

Table 1: Present Layout of Workstation

In this study, excavator assembly line was examined. Excavator are the earth movers which are mainly used to move debris from construction sites and demolish certain structures which weighs around 19.8 tonnes to 20.3 tonnes with a gross power of $123 \mathrm{KW}$.The operations and standardtimes of the Stations and feeders were studied in the layout. 
In the line-balancing to a chain of workstations all duties are to be assigned, and in order that the unassigned (idle) time across all workstations is to be minimized. Depending upon the basis of precedence relationship, which specifies the order in which the tasks are to be performed.In the assembly process to balance the production line, the necessary data are to be accumulated from the line. The data required were the cycle time and the non-value-added activities which will be not adding any value to the assembly line.

\section{Time Study}

While we received manufacturing and work information from the company, as well as found the factories in movement, we had a need to conduct our own time study to get the precise facts on the cycle times within every factory. In laying department which are engaging in the time study, gave us the observed cycle time instances for every lay. We additionally conducted time studies for the stations and feeders in which we found many regions of development, in addition we have also recorded the cycle time.

A time study is a established method of directly looking at and measuring human work so that you can set up the time required for the completion of that work.

We recorded the cycle times for operations conducted by personnel using a stop watch and pre-made tables. These cycle time gave us essential data, which we used in our VSM. The average cycle time informed us how nicely the current operation is doing when it comes to the TAKT time. TAKT time is the total available time divided by number of units that are in demand on that particular day.

The way we recorded cycle times, was to begin the stopwatch while the operator inserts a piece into the system, and then stop the watch while the operator inserts the subsequent piece into the machine. For every operation the number of operators and the quantity of pieces produced in each cycle is recorded.

\section{Line Balancing}

Line balancing involves making the amount of work and the amount of time to perform the work at each station as equal as possible.

- In simple words the task time should be less than the takt time.

- In this project, line balancing was carried out to provide proper allocation ofworkers across the workstation and to carry out the line balancing among thework stations.

- Various Line balancing methods like Largest Candidate Rule, Kill-Bridge andWester method and Ranked Positional Weights method. In this project we are using Largest Candidate Rule and Kill-Bridge andWester method to identify which method is best suited for the assembly line.

Largest Candidate Rule (LCR) Method Known as the main intention of the Line Balance is to distribute the entire workload on the assembly line as evenly as possible, in spite of the truth wherein it's miles impossible to obtain an ideal line stability of the various employees. It is then the function of line balance efficiency which is related to the differences in minimum rational work detail time and the priority constraints between the factors. The Largest Candidate Rule (LCR) accounts for work factors to be arranged in a descending order (close to the station time Ts, and work element) to each station Cycle time which isn't always exceeding the allowable preceded Ts.

For this Project, the line balancing technique is used, in which the workelements are arranged in the descending order according to the task time. Thealgorithm consists of the following steps:

1) Assign the elements to the employees at the primary workstations by using beginning on the pinnacle of the list and choosing the first element that satisfies precedence requirements and does no longer cause the whole sum of the task time at the station to exceed the allowable task time, while an element is selected for undertaking assignment to the station, begin again from the top of the listing for subsequent assignments.

2) When there are no more elements left that can be used without exceeding thetask time, we should proceed to the next station,

3) Repeat the following steps forother station in turn until all the elements have been assigned.

- By using this method, we can increase the productivity of the line by doing properallocations of workers and balancing the work stations

- The following calculations are done:

a)Balance delay $(\mathrm{d})=\left(\eta_{\text {actual }} * \mathrm{~T}_{\mathrm{s}}-\Sigma \mathrm{T}_{\mathrm{wc}}\right) /\left(\mathrm{\eta}_{\text {actual }} * \mathrm{~T}_{\mathrm{s}}\right)$

Balance delay- $\left(\mathrm{WT}_{\mathrm{s}}-\mathrm{T}_{\mathrm{wc}}\right) / \mathrm{WTs}$-It indicates the amount of time lostdue to imperfect balancing as a ratio to the total time available.

Where, w-no of workers

$\mathrm{T}_{\mathrm{s}}$ - Maximum available service time ( $\mathrm{min} /$ cycle)

$\mathrm{T}_{\mathrm{wc}}$-Work content time $(\mathrm{min} / \mathrm{pc})$-It is the total time of work elements thatmust be performed on the line to make one unit of product.

$\eta_{\text {actual- }}$ No of Workstations.

b) Line efficiency $(\eta)=(1-d) * 100$.

Where, d- Balance delay

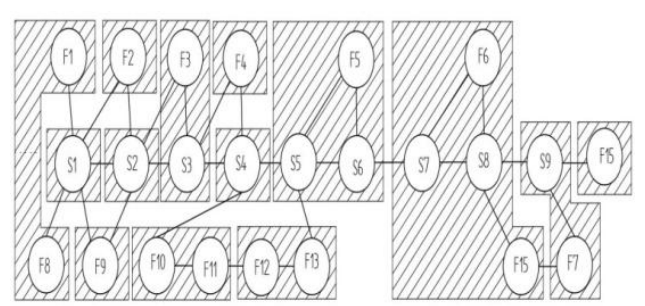

Figure 1: Present Workstations

The Following stations and feeders are combined according to their activities for example, after completing the operations in feeder 1 and feeder 8, the operations of Station 1 is carried out.

That is, in the excavator assembly feeder 1 block sub assembly takes place and in feeder 8 main control valve sub assembly are done these two operations are carried out to 


\section{EFFICIENCY IMPROVEMENT IN THE ASSEMBLY LINE WITH THE APPLICATION OF ASSEMBLY LINE BALANCING METHOD}

Station 1 where frame dress up Operation is completed. Similarly, the stations and feeders are combined according to their Operations by doing so We have got 14 Workstations out of 24 Stations and feeders.

\section{CALCULATIONS FOR PRESENT LAYOUT:}

Sum of Cycle Time - 1515.66 mins

Largest Cycle Time - 152 mins

Number of Work Stations - 14

Balance delay $(\mathrm{d})=\left(\eta_{\text {actual }} * \mathrm{~T}_{\mathrm{s}}-\Sigma \mathrm{T}_{\mathrm{wc}}\right) /\left(\mathrm{\eta}_{\text {actual }} * \mathrm{~T}_{\mathrm{s}}\right)$

$=(14 * 152-1515.66) /(14 * 152)$

$=(2128-1516.66) / 2128$

$=612.8 / 2128$

$\mathrm{d}=0.2872$

Line efficiency $(\eta)=(1-d) * 100$

$$
\begin{aligned}
& =(1-0.2872) * 100 \\
& \eta=71.27 \%
\end{aligned}
$$

As the initial efficiency calculated is $71.27 \%$ there is a scope for future improvement. In order to improve the layout, the activities carried out in the layout must be studied in detail to identify which of those activities are not adding value to the layout.

As per the observations done we have combined the feeder 1 and station 1 as Combined Station 1 and we have combined feeder 15 ' and feeder $15 "$ as feeder 15 . The combination of these stations is done by removing all the non-value-added activities and combining the value-added activities in each station. Hence Non-Value-Added Activities of following stations are shown in the below table 2.

By removing all the non-value-added activities 1515.66 mins were reduced to 1412.33 mins by saving 103.33 mins.

By combining the Station-1 \& feeder-1 and combining feeder-15'\& feeder-15" the non-value-added activities are eliminated. Thus, to find the efficiency largest candidate

\begin{tabular}{|c|c|}
\hline $\begin{array}{l}\text { STATIONS } \\
\& \\
\text { FEEDERS }\end{array}$ & NON-VALUE-ADDED ACTIVITIES \\
\hline 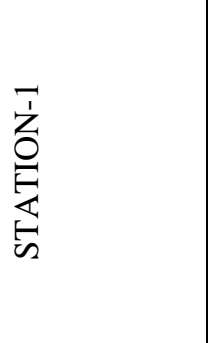 & $\begin{array}{l}\text { - Fixing the eye bolt \& Removing the } \\
\text { eye bolt on the upper frame } \\
\text { - Disassemble Hose } \\
\text { - Collecting the Teflon tap from the } \\
\text { work table, Insulating tap, Tools and } \\
\text { bolt strips. } \\
\text { - Taking Torque gun from work table } \\
\text { and Taking tool from Another station. }\end{array}$ \\
\hline 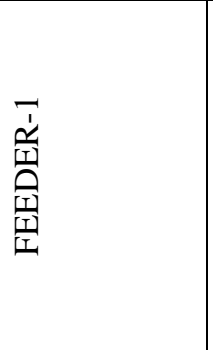 & $\begin{array}{l}\text { - Lifting and placing MCV \& Lifting } \\
\text { Tank } \\
\text { - Movement for MCV assembly point } \\
\text { - Moving to center of frame with tie } \\
\text { - Wrap (in front of MCV) } \\
\text { - Waiting for torque Wrench } \\
\quad \text { Taking out stool coming out from } \\
\text { frame }\end{array}$ \\
\hline 空各 & $\begin{array}{l}\text { - Reducing the duplication of work } \\
\text { (Bush fixing and dust seal } \\
\text { fixing,Dummy cap Fixing) }\end{array}$ \\
\hline
\end{tabular}
rule method is carried out for the proposed layout.

Table 2: Non-Value-added Activities

\section{PROPOSED LAYOUT}

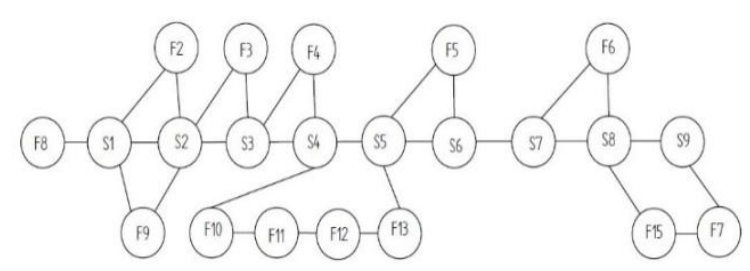

Figure 2: Proposed Layout of Workstations

In the Proposed layout Feeder 1 is combined with Station 1 and Feeder 15' and Feeder 15" were combined as a single Feeder 15 station. Now Arrange All the Workstations According to Their Respective Operations and Create a Precedence Table

\begin{tabular}{|c|c|c|}
\hline ELEMENT & $\begin{array}{c}\text { ELEMENT } \\
\text { TIME (MINS) }\end{array}$ & PRECEDENCE \\
\hline FEEDER 8 & 67 & -- \\
\hline STATION 1 & $82: 50$ & F-8 \\
\hline FEEDER 2 & 80 & S-1 \\
\hline STATION 2 & 120 & F-2, S-1, F-9 \\
\hline FEEDER 3 & 38 & S-2 \\
\hline STATION 3 & 52 & F-3, S-2 \\
\hline FEEDER 4 & 61 & S-3 \\
\hline STATION 4 & 111 & S-3, F-4 \\
\hline STATION 5 & 74 & S-4, F-13 \\
\hline FEEDER 5 & 8 & S-5 \\
\hline STATION 6 & 62 & S-5, F-5 \\
\hline STATION 7 & 27 & S-6 \\
\hline FEEDER 6 & 16 & S-7 \\
\hline STATION 8 & $26: 40$ & S-7, F-6 \\
\hline FEEDER 15 & 95 & S-8 \\
\hline FEEDER 7 & 28 & F-15 \\
\hline STATION 9 & $69: 20$ & S-8, F-7 \\
\hline FEEDER 9 & 152 & S-1 \\
\hline FEEDER 10 & $55: 40$ & S-4 \\
\hline FEEDER 11 & $66: 30$ & F-10 \\
\hline FEEDER 12 & $38: 20$ & F-11 \\
\hline FEEDER 13 & 82 & F-12 \\
\hline
\end{tabular}

Table 3: Precedence Tableof Work station

In the next step table arrange all the Stations and Feeders in Descending order with respective to their cycle time

\begin{tabular}{|c|c|c|}
\hline ELEMENT & $\begin{array}{c}\text { ELEMENT } \\
\text { TIME (MINS) }\end{array}$ & PRECEDENCE \\
\hline FEEDER 9 & 152 & S-1 \\
\hline STATION 2 & 120 & F-2, S-1, F-9 \\
\hline STATION 4 & 111 & S-3, F-4 \\
\hline FEEDER 13 & 82 & F-12 \\
\hline STATION 1 & $82: 50$ & F-8 \\
\hline FEEDER 2 & 80 & S-1 \\
\hline STATION 5 & 74 & S-4, F-13 \\
\hline STATION 9 & $69: 20$ & S-8, F-7 \\
\hline
\end{tabular}




\begin{tabular}{|c|c|c|}
\hline FEEDER 4 & 61 & S-3 \\
\hline FEEDER 8 & 67 & -- \\
\hline FEEDER 11 & $66: 30$ & F-10 \\
\hline STATION 6 & 62 & S-5, F-5 \\
\hline STATION 3 & 52 & F-3, S-2 \\
\hline FEEDER 15 & 59 & S-8 \\
\hline FEEDER 10 & $55: 40$ & S-4 \\
\hline FEEDER 3 & 38 & S-2 \\
\hline FEEDER 12 & $38: 20$ & -11 \\
\hline FEEDER 7 & 28 & F-15 \\
\hline STATION 7 & 27 & S-6 \\
\hline STATION 8 & $26: 40$ & S-7, F-6 \\
\hline FEEDER 6 & 16 & S-7 \\
\hline FEEDER 5 & 8 & S-5 \\
\hline
\end{tabular}

Table 4: Activities in Descending Order

After arranging the Stations and Feeders in descending order. Form the Workstations by clubbing the Stations and Feeders according to their operation and element time, where Total Element time should be below 152 mins being the highest cycle time.

\begin{tabular}{|c|c|c|c|}
\hline $\begin{array}{c}\text { WORK } \\
\text { STATION }\end{array}$ & ELEMENT & $\begin{array}{c}\text { ELEMENT } \\
\text { TIME } \\
\text { (MINS) }\end{array}$ & $\begin{array}{c}\text { TOTAL } \\
\text { ELEMENT } \\
\text { TIME } \\
\text { (MINS) }\end{array}$ \\
\hline I. & $\begin{array}{l}\text { F-8 } \\
\text { S-1 }\end{array}$ & $\begin{array}{c}67 \\
82: 50\end{array}$ & $149: 50$ \\
\hline II. & F-2 & 80 & 80 \\
\hline III. & F-9 & 152 & 152 \\
\hline IV. & S-2 & 120 & 120 \\
\hline V. & $\begin{array}{l}\text { F-3 } \\
\text { S-3 } \\
\text { F-4 }\end{array}$ & $\begin{array}{l}38 \\
52 \\
61\end{array}$ & 151 \\
\hline VI. & S-4 & 111 & 111 \\
\hline VII. & $\begin{array}{l}\text { F-10 } \\
\text { F-11 }\end{array}$ & $\begin{array}{l}55: 40 \\
66: 30\end{array}$ & $122: 10$ \\
\hline VIII. & $\begin{array}{l}\text { F-12 } \\
\text { F-13 }\end{array}$ & $\begin{array}{c}38: 20 \\
82\end{array}$ & $120: 20$ \\
\hline IX. & $\begin{array}{l}\text { S-5 } \\
\text { F-5 } \\
\text { S-6 } \\
\end{array}$ & $\begin{array}{c}74 \\
8 \\
62 \\
\end{array}$ & 144 \\
\hline $\mathrm{X}$. & $\begin{array}{l}\text { S-7 } \\
\text { F-6 } \\
\text { S-8 }\end{array}$ & $\begin{array}{c}27 \\
16 \\
26: 40 \\
\end{array}$ & 69:40 \\
\hline XI. & $\begin{array}{l}\text { F-15 } \\
\text { F-7 }\end{array}$ & $\begin{array}{l}95 \\
28\end{array}$ & 123 \\
\hline XII. & S-9 & 69:20 & $69: 20$ \\
\hline
\end{tabular}

Table 5: Workstation Table

\section{CALCULATION}

Figure 3: Proposed Layout with 12 workstations

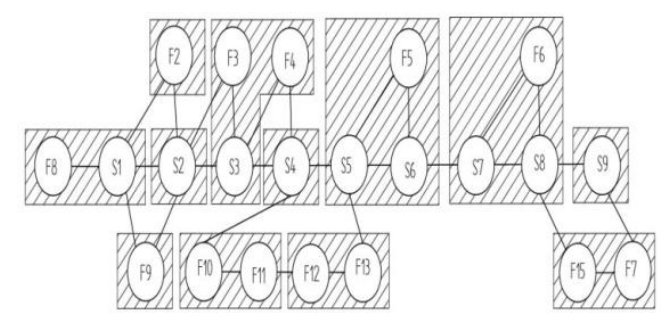

- $\mathrm{T}_{\mathrm{wc}}=$ An assemble product requires a certain total amount of time to build, called the work content time $\left(\mathrm{T}_{\mathrm{wc}}\right)=1412.33$ minutes

- $\mathrm{w}=$ no of work station $=12$

- $\mathrm{T}_{\mathrm{c}}=$ the maximum available cycle time $=152$ minutes

- $\quad$ Balance delay $(\mathrm{d})=\left(\eta_{\text {actual }} * \mathrm{~T}_{\mathrm{s}}-\Sigma \mathrm{T}_{\mathrm{wc}}\right) /\left(\mathrm{\eta}_{\text {actual }} * \mathrm{~T}_{\mathrm{s}}\right)$ $=(12 * 152-1412.33) /(12 * 152)$ $=(1824-1412.33) / 1824$ $=411.67 / 1824$

$\mathbf{d}=0.2256$

- $\quad$ Line efficiency $(\eta)=(1-d) * 100$ $=(1-0.2256) * 100$

$$
\eta=77.44 \%
$$

\section{RESULTS AND DISCUSSION}

The detailed study of the excavator assembly line identified the importance of cycle time study and the line balance. This led to identification of those activities which were duplicated and added no value to the assembly line, rather it added extra time to the activities. This led to the improvement in the assembly line. Initially the efficiency was found to be $71.27 \%$. By removing the duplication and unnecessary work in the stations and feeders led to the improvement in the efficiency and few standard operations were implemented. Thus, by applying LCR method we have found the increase in efficiency in the proposed layout i.e. $77.44 \%$ with the improvement of $6.17 \%$

\begin{tabular}{|c|c|c|c|}
\hline & $\begin{array}{c}\text { Existing } \\
\text { method }\end{array}$ & $\begin{array}{c}\text { Proposed } \\
\text { method }\end{array}$ & Improvement \\
\hline $\begin{array}{c}\text { Line } \\
\text { Efficiency }\end{array}$ & 71.27 & $77.44 \%$ & 6.17 \\
\hline $\begin{array}{c}\text { Balance } \\
\text { Delay }\end{array}$ & 0.2872 & 0.2256 & 0.0616 \\
\hline
\end{tabular}

Table 6: Results

\section{CONCLUSION}

This paper describes assembly line balancing is one of the major steps to be taken into consideration while increasing productivity of Excavator industries. Line balancing is done with taking in account the takt time, cycle time and downtime and thus reduces the production lead time with increased number efficiency. Continuous improvement is the step to reduce unnecessary downtime losses.

Eliminating feeder-1 and feeder-15, has helped to increase the line efficiency from $71.27 \%$ to $77.44 \%$

The following benefits after eliminating feeder- 1 and feeder-15 are: -

- Lifting and placing on fixture, where as it can be placed directly on the trolley and sub assembly can be done. Lifting and placing on pallet is eliminated after doing the sub assembling

- Laser Aid for frame Feeding is Introduced in the place of Feeder 1.

- A total of 103.33 minutes is eliminated. Which includes certain non-value-added activities.

Published By:

Blue Eyes Intelligence Engineering 
- Moving the trolley from feeder-1 to station-1 is eliminated as it comes directly from the stores and placed on the trolley of station-1

By using the technique of line balancing, we have brought down the work station from 14 to 12 after eliminating feeder-1 and feeder-15. The line efficiency is also measured with Largest Candidate Rule method and can be used as a signal to perform further analysis and improvements if it exhibits sudden changes.

\section{REFERENCES}

1. Nurul NazeerahMishan and Masine Md Tap, "Increasing Line Efficiency By Using Time Study And Line Balancing In A Food Manufacturing Company” JurnalMekanikal Dis 2015

2. Anil Jaggi, Dr. Sidheswar Patra, Prof. (Dr.) D. S. Chaubey, "Application of Line-balancing to Minimize the Idle Time of Workstations in the Production Line with Special Reference to Automobile Industry" International Journal of IT, Engineering and Applied Sciences Research (IJIEASR) Volume 4, No. 7, July 2015

3. Swapnil T. Firake, Dr. K. H. Inamdar, " Productivity Improvement of automotive Assembly Line through Line Balancing" International Journal of Technical Research and Applications e-ISSN: 2320-8163,

4. DR. Ikon, M.A and Nwankwo Catherine Nkechi, "Line Balancing And Performance: A Study Of Selected Breweries In Anambra State, Nigeria" International Journal of Business and Management Review Vol.3, No.8, pp.29-43, September 2015

5. K Syahputri*, R M Sari, Anizar, I Rizkya, J Leviza and I Siregar, "Improving Assembly Line Balancing Using Moodie Young Methods on Dump Truck Production"The 2nd Annual Applied Science and Engineering Conference (AASEC 2017) IOP Publishing.

6. Tushar Shah, Dr. G. S. prakash, "Improvement in Line Efficiencyof Assembly Lineby Using Assembly Line Balancing Techniques" International Journal for Research in Applied Science \& Engineering Technology (IJRASET), ISSN: 2321-9653; IC Value: 45.98; SJ Impact Factor:6.887

7. Ankur Malik1, UmedKhod, "Experimental Study For Assembly Line Balancing Using Largest Candidate Rule Algorithm In Automobile Lighting Industries A Case Study" International Journal of Technical Research (IJTR) Vol. 5, Issue 1, Mar-Apr 2016 